\title{
Empirical findings on the forest law and policy in Bangladesh
}

\section{Noor Mohammad}

Faculty of Law, Universiti Kebangsaan Malaysia 43600, The National University of Malaysia, Bangi, Selangor DarulEhsan

Email address:

noormmu2011@gmail.com (N. Mohammad)

\section{To cite this article:}

Noor Mohammad. Empirical Findings on the Forest Law and Policy in Bangladesh, Agriculture, Forestry and Fisheries. Vol. 2, No. 2, 2013, pp. 49-66. doi: 10.11648/j.aff.20130202.11

\begin{abstract}
Forest and forest resources are one of the important factors for the conservation and development of the environment and environmental resources in Bangladesh.It is observed that these natural resources of our country are not properly utilized but it is often exploited due to over population, unwise use of natural resources etc. To cope with these problems, some important legal foundations have already been passed for effective role in the development of forest and forest resources of Bangladesh. The study finds that most of the forest laws and policies are originated from the rule of British colonial authorities. In this regard, some significant amendments of the laws are made after the partition of the Indian subcontinent and a few are also amended after the independence of Bangladesh. In 1990s, some important integrated Acts such as the Bangladesh Environment Conservation Act, 1995 and its Rules, 1997 and the Environment Court, 2000 etc., are passed for the development and conservation of the environment of Bangladesh which enormously carried out for the protection of the forest and forest resources in Bangladesh. There are some limitations such as lack of enforcement, noncoordination, corruptions, outdated laws, insufficient penal provisions etc., which makes hindrance to the implementation of the forest laws and policies in Bangladesh. It is suggested that the policy implications framed in this study should strictly be emphasized for the implementation as to bringing about sustainable forest environment and development of Bangladesh.
\end{abstract}

Keywords: Forest Law, Forest Policy, Forest Resources, Empirical Findings, Bangladesh

\section{Introduction}

Forest is a sub sector of agriculture and it is one of the main components of the environment, which has been contributed a lot to mankind conserving sound environment on the earth. It is contributing a significant part to national economy and it is playing predominant role in maintaining ecological balance. The forest sector accounts for 1.86 percent of total GDP and 10.2 percent of agricultural income in 2002-03. At present, the growth rate of this sub-sector is 5.0 percent. The total 45 percent has tree coverage [1].Around 2 percent of total labour forces in the country are engaged in forestry sub-sector. Increasing growth of population, trespassing in forests, large-scale felling of trees for use as fuel, have had adverse impact on environment. The Government has undertaken a comprehensive forest development program aimed at large scale afforestation and preservation of forests in the country, offsetting depletion of forest, ensuring supply of raw materials for timber-based industries, preservation of biodiversity and wildlife. With these goals, a twenty-year, (1995 to 2015) Forestry Master
Plan has been approved [2].The Master Plan is manufacture oriented and participatory and also endeavors at strengthening institutional facilities. Steps that have been undertaken by the Department of Forest during, 2002-2003 for effective implementation of policies under the Master Plan.But the forest environment is exploited in many ways and in various forms. To cope with these problems, the Government has taken many initiatives to develop and conserve the forest and forest resources in the country. In this regard, a good number of forest legislations are actively carried out for the protection and conservation of the forest ecosystems in Bangladesh. But its legal foundation is not effective for the protection and management of the forest resources in Bangladesh [3]; because existing laws are almost inadequate and out dated. Those laws have already been unenforceable due to present socioeconomic changes of the country. Most of the forest laws are promulgated before the independence of Bangladesh and are only recently being revised and updated or yet to be updated [4].During the British period 1757-1947, few forest laws were passed to develop the forest resources of Bangladesh. But the devel- 
opment of laws and policies were increasing in course of time. In fact, these laws were made only to serve the interests of British colonial authorities [5].There are four Acts including 3 Ordinances, 16 Rules, and some other amendments of the forest laws passed to protect the forest and forest resources of Bangladesh. In this regard, the Government of Bangladesh has formulated some policies and action plan to develop the forest ecosystems in the country. The Government of Bangladesh has enacted the Bangladesh Environment Conservation Act, 1995 and its Rules, 1997 to protect the environment dealing with the forestry, fisheries, agriculture etc., of Bangladesh. Moreover, the Government has established two Environmental Courts to dispose of the cases related to environmental pollution and offences.In this regard, the Environmental Court actively carried out for developing the forest resources of Bangladesh. The paper explores the implementing problems of the social forest law and policy with a view to assessing its potentialities, constraints. Moreover, some policy implications will be put forwarded in this regard.

\section{Methodology}

This research work has been undertaken in the sadar districts of Khulna, Jessore, and Jhenidah of Bangladesh. Some methods such as Interview, Formal and Informal Discussions through structured and unstructured questionnaire, Observation are used for this study.Most of the respondents are the Government officials in forest department. But the respondents are not specified in number because; the Government officials are very busy at their works yet; around 20 to 25 respondents on the basis of different criteria were selected for this work. It is found that most of the respondents did not answer to my answer properly. For that reason, the observation method is given priorities. The researcher has already done a study on fisheries and agriculture of Bangladesh. He has observed that the problems of forest laws and policies are as similar as those of agriculture and fisheries of Bangladesh. That is why; the barrier and policy implications of forest laws and policies are sometimes discussed in relation with the agricultural and fisheries laws of Bangladesh. Moreover, forestry, fisheries and agriculture are entire related. The researcher has given emphasis on the causes, which stand in the way of the implementation of the forest laws and policies of Bangladesh. This study is solely applicable to the social forest laws and policies of Bangladesh. The researcher thinks that the observation method is appropriate as it involves legal issues and respondents are not really willing to talk to this sensitive issue. Based on it, I would like to add that we are able to get good results.

\section{Background}

Forest and forestry though not much facts is available, some research works indicate that extensive forest under tropical range existed in the tertiary period in parts of Bangladesh. It is observed through the legislative history that
Bangladesh, India and Pakistan have the identical legislative up to 1947 on the management and administration of forest in this sub-continent [6].In general, the problems regarding forest management are broadly same in all the three countries. The pre-independence forest law still provides the basic legal provisions. In this regard, at present Bangladesh faces worse situation than those of Pakistan and India. Glutaxylan, Dipterocapoxylon, Cynometroxylon fossils, all from Miocene beds, discovered in adjacent areas have affinities with species found today in tropical conditions. A good number of Angiosperm plant fossils are also observed from the areas adjacent to Bangladesh [7].The tertiary period was followed by a period of glaciation. Some advancement occurred during the Pleistocene period, starting from around a million years ago, and ending at 25000 BC. But these advancements were interrupted by interglacial periods, when the climate became less cold. This lowering of temperature eliminated most mammals and also helped in extinction of tertiary and Siwalik flora.In the proto- historic period, civilization flourished in the Sind and Punjab (dating $4000 \mathrm{BC}$ to $5000 \mathrm{BC}$ ); people then were great users of timbers. No record, however, is available about the forests of Bengal for the period [8].There is evidence of a flourishing Dravidian civilization in 2000 BC. The forests had a great role to pay in the development of this civilization. The early Aryans were pastoral people, interested in agriculture. They cleared forests in certain areas to settle down and maintained all their industries in the sylvan surroundings of the forest. Vedas, Brahmanas, Aranakas, and Puranas throw light on the forest and forestry of the subcontinent during those periods, and their distribution and composition can be conjectured from the twoliteracy contribution of the post-Vedic period, viz. Ramayana, and Mahabhrata. Frequent references of Sal (Shorearobusta), Dhab (Anogeissuelatefolia), Billa (Aeglemarmelos), kinsuka (Buteamonosperma), etc., have been made which are common species in Bangladesh forests. In the epics, it is recorded that dense forests existed along the Ganges but it is difficult to ascertain from the description where the forest was located. The next period to take into consideration is the period of Greek invasion and the Maura Kingdom. Megasthenes described the period as one when many huge mountains abounded in fruit trees and many vast plains of great fertility more or less beautiful but all alike interested by multitudes of rivers. Emperor Ashoka was a great lover of forests and wildlife and took initiatives to preserve them. Hiuen -Tsang voyaged India between 629-645 AD [9]. His memoir gives extensive information on the distribution of forests at that time. During the Mughal period, incentives were given to reclaim forest areas for agriculture. Babar in his diaries well known that Bengal Suba had 24 Sirkars including 5 in Orissa. AbulFazal mentions presence of forests in Jannatabad, Khalifabad and Bazuha. In Khalifabad, he mentions plenty of wild elephants; while in Bazuha thick long timbers suitable for masts. Jannatabad was grassy and full of wild buffaloes. The present Sundarbans, according to the description, extended further north up to northern Nadia 
and northern Jessore, and were full of crocodiles and tigers. The Mughal policy on forest was one of indifference. They used the forests mostly as game reserves for the purpose of sports. They were interested in trees from the gardening point of view, and also for avenue planting. In short, it may be said that they had a creative and capable outlook on plants, rather than any comprehensive policy on problems of forestry including its preservation, propagation, protection or improvement. The end of the Mughal period was followed by the beginning of East India Company and later the British rule. Primarily, i.e. in the 18th century up to the middle of the 19th century, the forests were subjected to exploitation on an enormous scale for shipbuilding and railway sleeper production. There was no real endeavor at forest preservation. The forest attempt was taken in the southern part of India. On 3r August 1855, Lord Dalhoshie, Governor General of India, issued a memorandum where for the first time; he proclaimed a plan for forest conservancy for the whole of India. According to Stabbing, it may be called the Charter of the Indian Forests. Brandis in 1856 was appointed as the Inspector General of Forests. A Forest Department was established during British Rule for the first time on Ist November 1864. Scientific Forest Management in India started under Brandis. He was assisted by Cleghora. In 1865, the Indian Forest Act was passed, and the Forest Service was organized in 1869 . By 1870 , the foundation of the Forest Department may be said to have been laid by Brandis. A regular forest service began to exist and definite progress in forestry started between 1971-1900. Forests were separated and the Forest Act was revised in 1878 (Act VII of 1871). Between 1871 and 1900, steps were taken to organize technical education and training of personnel to fill up the executive and controlling of personnel to fill up the executive and controlling branches of the forest service. The first forest School was opened in Dehradun, India in 1878. In 1906, Lord Curzn opened the Imperial Forest Research Institute at Dehrandun.In 1879, 4856 sq. km (1875 sq miles) of Sundarbans were declared as Protected Forest and in 1893 Heinig prepared a working plan of the Sundarbans. In 1880, closure to shooting, hunting, and fishing was first applied. In 1867, Leeds joined as conservator of Forests after the resignation of Anderson. In 1872, Schlieh joined as conservator of Forests. In 1925, EO Shebbare started systematic inquiry into private forests. The forest administration of East Pakistan was reorganized. First into two, and then into three circles, namely, Eastern, Western, and Development circles.Chittagong, Cox's Bazar, Chittagong Hill Tracts and Syhlet constituted the Eastern Circle; Sundarbans, Dhaka, and Mymensingh the Western circle; and the Working plan, and Utilization Divisions remained under the Development Circle. A school to train foresters was established at Syhlet. In 1960, the post of Chief conservator of Forests was formed. A college for training Forest Rangers was also established in Chittagong. The Forest Research and Training of Superior Service Officers remained as a Central Government subject and was controlled from Rawalpindi (West Pakistan) by the Inspector General of Forests. Through a resolution, the government of Pakistan transferred the Forest Research Institute to the East Pakistan Government and provided funds to convert it into a full-fledged forest research Institute in East Pakistan. The political changes followed by the creation of Bangladesh in 1971 led to a new forest policy. Efforts began in 1972 to implement the policy 'Forestry for all' became the call, and more emphasis was placed to extend tree resources beyond the 'reserve forests' and steps adopted to plant trees in fallow, marginal lands, and in village groves. Measures to protect the biodiversity were also taken. Remarkable changes have occurred in the administrative setup of Bangladesh forests since 1980 [10].Social forestry has got more importance and districts with no or least forests have been brought under the canopy of social forestry. New forest divisions were created in Rangpur in Khagrachari, Bandarban, Kaptai and Rangamati to create plantations in the treeless unclassed state forests.

\section{Brief History}

It is observed that most of the laws including forest laws prevailing in the country are the origin of the British colonial authorities. In the Indian subcontinent, it is also noted that the forest law is basically enacted in 1878. In this regard, Bangladesh also inherited the forest laws from the British enacted laws. A good number of forest laws are carried out for developing and promoting the forest resources in Bangladesh in order to meet the changed society's requirements of the country. According to the Forest Act, 1927 , it has been existed about $18 \%$ or 2.6 million hectares of forestland under the supervision of the Department of Forest in Bangladesh. Of them 2.4\% has been destroyed and $6 \%$ to $8 \%$ out of $10.3 \%$ is now environmentally endangered [11].Deforestation and large scale cutting of trees can produce extremely harmful effects and increased radiation will cause atmospheric temperature increasing. Due to increasing rate of temperature, large soil particles will integrate high day temperature and will cause a breakdown of homes with consequent biotic changes, which may result in a deterioration of soil quality. In the absence of the wind shelter of trees, soil moisture is created. There shall be tree roots to bind the soil, and when rain falls and the water run off occurs, there will be large-scale soil erosion and loss of the fertile topsoil. There are serious consequences, which in the long run will prove disastrous have happened West Rajasthen. In the continuation of the past 20 years, now, the environment of forest is at stake in Bangladesh. Forest bears a great significance to the economy and ecological stability of Bangladesh. Most of the forests are located in Chittagonj Hill Tracts, Khulna district, Sylhet Dhaka, Mymensingh and Tangail. At present, Bangladesh is not rich in forest resources. This contribution has greatly declined over the past several decades. The forest area comprises only 17 percent of its land out of which Forest Department manages about $10 \%$. However, only $6 \%$ of these lands are under canopy forest cover. Off-forest land covered by trees is 
about $7 \%$. In the other source, it is mentioned that the forest areas comprises only $9 \%$ of its land, which is very injurious to life on earth and is also difficult to lead life. The deforestation and temperature rate becomes very high in compatible to life due to the improper use of tress, disobedience to law relating to forest etc Bangladesh is over populated and there is a tremendous demand for the use of woods for agriculture, aquaculture, homestead, and other purposes. Therefore, deforestation rate is too high. There is need to arrest the declining trend of forestry. Contribution of the forest sector to GDP is 3.3\% at current prices [12].It is universally accepted principles that $25 \%$ of the forest is required for maintaining ecological balance in any country or region of the world. The National Forest Policy, 1894 provides the basic guidelines for the formulation of acts and rules for the management of forests in the country. This attempt was made in 1855 for conserving forest resources by the British India through the promulgation of the Charter of Indian Forests. After the partition of India in 1947, the policy was not relevant for the new state of Pakistan, which inherited forest cover for less than $2 \%$ of its territory. The existing policy neither contemplated the increase of forest area nor emphasized sustained harvest from existing forests. Furthermore, it excluded private forests from its ambit. These deficiencies were reorganized in the Pakistan Forestry Conference held in 1949. The conference guidelines provided improvement upon the policy statement of 1894 and a new Forest Policy was announced in 1955. The Forest Policy, 1955 was further revised and the Forest Policy of 1962 was introduced. The Forest Policy of 1955 and 1962 laid emphasis on the exploitation of forest produce, particularly from East Pakistan [13].The policies did not help the development of forestry in Bangladesh and were not very favorable for all round growth of forestry.In addition, increase in population and increased demand for food and other essentials resulted in heavy pressure on forestland, leading to ecological degradation. Even though Bangladesh became independent in 1971 and its National Forest Policy was not announced until 1979.

The policy announcement of 1979 is very common and ambiguous. Most of the essential aspects such as purposeful classification and use of forest land, role of forest as the ecological foundation of sustainable biological productivity, community participation in forestry, etc., did not get any mention in the policy declaration. Consequently, the Government decided to amend the Forest Policy of 1979. The amended Forest Policy known as Forest Policy, 1994. In the early 1990s, a 20 -year Forestry Sector Master Plan, 19932012 was developed, which aims to bring $20 \%$ of the country's land area under tree cover.

\section{Significance}

The forests of a country make an asset of immense value to the human society and mankind as well. Its important areas are as follows:

- Forests provide a number of products such as timber, firewood, fruits and seeds, clothes, medicines, furniture, house building materials, etc.

- Forest shape natural environment by influencing such factors as temperature, humidity and precipitation.

- Forest plays the most important role in keeping the atmospheric balance by consuming $\mathrm{CO} 2$ and producing $\mathrm{O} 2$, the latter being essential for the animal life.

- Forests prevent soil erosion and even flood.

- Forests maintain biogeochemical cycles of water, carbon, nitrogen oxygen, phosphorus, sulfur and a number of other chemicals.

- Forests help in public health protection by reducing physical and chemical contaminants of the environment.

- Forests provide suitable habitats for large number of plant and animal species.

- Forests are the valuable resources to the study and research in various branches of natural sciences.

- Forests have great aesthetic value. All People appreciate the beauty and tranquility of forests.

- For maintaining ecological balance or environmental balance.

- Helpful for reducing poverty.

- Helpful for creation of job opportunities etc.

\section{Causes of Deforestation}

The deforestation rate in Bangladesh is very high in comparison to India, Indonesia, Thailand, and Philippines etc., of the world. Deforestation rate of Bangladesh is about $3.3 \%$, which is $0.6 \%$ of South Asia. There are many causesof deforestation in Bangladesh such as population pressure /overpopulation, wide-range of poverty; settlement or mitigation of land less people in the forest areas, shifting cultivation, inappropriate exploitation of forest resources, grazing, illegal feeling; for fuel wood uncontrolled and wasteful commercial exploitation, lack of awareness of the value of forests, historical changes in the ownership of the forests especially the enactment of the East Pakistan Private Forest Act of 1949 (Act of 1950), the enactment of the East Pakistan State Acquisition and Tenancy Act, 1950 worked as incentives for felling trees indiscriminately, partition of the sub-continent, and transfer of the forest to the forest department and natural phenomenon also caused deforestation [14] . It creates some impacts such as rare wildlife and biological diversity that have also reduced quite rapidly, many species have disappeared altogether, human habitat, the life and culture of the forest communities have also be severely affected, and ethnic communities are also seriously affected etc.; [15].

\section{Major Initiatives}

The government of Bangladesh has taken many initiatives for the development and protection of the forest and forest resources of Bangladesh. The initiatives are observed since the independence of Bangladesh.Since deforestation is a great problem and that is why; the Government as well 
as the Non-Governmental Organizations has taken many steps both in the national and international arena to protect the forest environment for combating deforestation in the country. The following institutions and their formulated strategies are working in this regard:

- The Government Research Organizations.

- Forest Research Institute.

- Bangladesh Forest Industries Development Corporation.

- Bangladesh Council for Scientific and Research (BCSIR).

- SPARSO.

- The Ministry and Department of Government of Bangladesh.

- Ministry of Environment and Forest (MOEF).

- Ministry of Agriculture.

- Ministry of Fisheries.

- Ministry of Industry.

- Department of Environment under the Ministry of Environment and Forest.

- The policies of Government relating to forest environment may be taken into consideration to protect the environment.

- The Environment Policy, 1992.

- The Forestry Master Plan, 1997.

- Forest Policy 1994 and Forestry Sector Master Plan, (1995-2015).

The Government of Bangladesh first formulated the National Forest Policyin 1979 [16]. This policy has not taken into consideration the village forestry resources, the main supplier of the country's forest produce. It had not given due stress on people's participation in augmenting forest resources in the country which has become absolutely necessary under the changed socio-economic legal scenario.But as the situation began to change with increased demand for forestry products and consequent depletion of forest resources and degradation of the overall environment, the Government had to update it and formulate a revised policy, which is known as the Forest Policy in 1994 [17].Most of the forest and forest resources are under the control of the Department of Forest, Ministry of Forest and Environment. Its main responsible is the protection and scientific management of the forest environment of Bangladesh so that the environment is not distressed and the resources are sustained.

Moreover, the Government at present is giving emphasis on the social forestry, which is a major portion of the forest in Bangladesh. It bears very important role for the protection, and conservation of the environment of the country. Presently, the Government has been working for the development of the social forestry for the purposes of building up a green society of the country. The social forestry is actively carried out throughout the country. The government has taken many initiatives for the development of the social forestry in Bangladesh. In this regard, six factorssuch as permanent tenure of land, profit maximization, prescribe team or group work, training, saving programs, gross profit sharing system are the main factors of the social forestry.

\subsection{Environment Policy Relating to Forest}

Environment policy is a collection of decisions that governs the general aims and objective of governing bodies. It is also a political commitment and it depends upon the existing Government bodies. The Environment Policy has made some sectoral environment policies such as fisheries, agriculture, animal husbandry, forestry etc. Environment includes water, air, soil and physical properties and the inter relationship which exists among them such as human beings, other living creatures, plants and microorganism. But the natural resources are unregulated and misuse of existing natural resources and the peaceful co-existence of these components and the resources are being threatened [19].It is mentionable here that, the Environment Policy of 1992 has few provisions regarding the conservation of forest and forest resources of Bangladesh which are not enough to meet up the needs [20].It is short-term and temporary policies, which cannot contribute to the development of forest and forest resources for achieving the conservational goal [21]. Forest is an important sector of environment. The government has formulated the Environment Policyand action plan in1992. Later, the National Forest Policy was passed in 1998 for the promotion and protection of the environment of Bangladesh [22]. The Environment policies are given here:

- Conserve, expand and develop forest to sustain the ecological balance and meet the socio-economic needs and realities.

- Include tree plantation programs in all relevant development schemes.

- Stop shrinkage and depletion of forestland and forest resources.

- Develop and encourage use of substitutes of forest products.

- Conserve wildlife and Biodiversity, strengthen related research and help insemination and exchange of knowledge in the concerned area.

- Conserve and develop wetlands and protect migratory birds.

The Government has implemented several projects for developing biodiversity conservation for all beings on earth. The biodiversity project is held in Khulna for Sundarbans development and conservation. But it is observed that the proper environment impact assessment is often overlooked which is a gross violation of the Bangladesh Environment Conservation Act, 1995 and its Rules, 1997 [18].

\subsection{National Forest Policy}

Since independence, it is observed that different governments of Bangladesh have been taking many initiatives to develop the forest and forest resources of Bangladesh. But its history is too long to describe. There were available a few information relating to forest earlier in 1800 . At that time, most of the forests were considered as God-gifted and the people had access to most of its products.

The Government has formulated the following National 
Forest Policy in 1979 [23].

- All forest land in the country shall be carefully preserved and scientifically managed for qualitative improvement.

- Government forest shall be designated as national forests and shall not be used for any purpose other than forestry; and horizontal expansion of the forests shall be in new land formations in the coastal belt and offshore areas, in the depleted hills of the Unclosed State Forests and in suitable khas lands.

- Tree and timber wealth shall be increased by large scale planting through mass participation and optimum extraction of forest produce shall be undertaken to meet national requirement.

- Utilization of forest produce based on modern trend and technology shall be ensured.

- Measures for meeting the raw material requirements of forest based industries from national forests and for setting up of new forest based industries shall be adopted

- Research, education and training in forestry shall be organized so as to scientific, technological and administrative needs of the forest sector in the country.

- Measures shall be adopted for managing the forest sector by members of a cadre of officer constituted for that purpose.

- Relevant laws shall be updated for the purpose of implementation of the national forest policy and the forest sector shall be organized as a separate administrative unit of the Government.

- Steps shall be taken for the conservation of forests for protection of natural environment and preservation of wildlife and for full utilization of recreational potentialities of forests; and technical assistance shall be extended to those interested in forestry.

This policy was first adopted in 1979 to safeguard and scientifically manage the forest but has been slow in implementation. It does not stress the importance of designating protected forests versus productive forests. It also does not recognize the significance of preserving genetic diversity and the ecosystem of the forest within the scheme of sustainable development. Although forestry laws have recently been revised, a comprehensive review and a wellintegrated policy reform within a multicultural framework are still needed for the purpose of developing forest environment in Bangladesh.

\subsection{Forest Action Plan}

The Government of Bangladesh has formulated and passed the following action plans for the purposes of developing and conserving the forest and forest resources in the country.

- Steps will be taken to protect present forest resources, prevent deforestation and effect extensive afforestation.

- Enrichment plantation of reserve forests will be accelerated.

- Forest Growing more trees and enriching forest resources in the rural areas will be given priority agro- forestry will be encouraged to promote multiple use of land, economic and environmental development through extensive implementation of social forestry and homestead forestry.

- Forest industries will actively attempt to explore alternative source of raw material. They will also make efforts to grow and procure their own raw materials either directly or indirectly.

- Development projects in all sectors will incorporate and implement the government decision of forestation.

-Effective measures will be taken to ensure direct participation of women in afforestation programs in thanas and villages.

- Priority will be given to the protection of wildlife, wetlands, birds and animals. Research and development projects will ensure protection of nearly extinct species.

- The present prohibition on hunting and export of wildlife and wildlife hides will continue. Prevention of wildlife habitats, establishment of wildlife sanctuaries will be encouraged.

- Research on biodiversity, exchange of knowledge and experience will be strengthened. For this purpose, research and information centers will be established and surveys will be conducted to assess latest status of wildlife and biodiversity.

- Alternative building materials and fuel sources instead of wood and import of wood will be encouraged.

- Regular surveys and research will be conducted to assess the state of deforestation, forest expansion and afforestation.

\subsection{Forest Action Plan Authorities}

The Government of Bangladesh has setup implementing agencies for undertaking the implementation of the forest policies in Bangladesh. The implementing authorities are the following a) Ministry of Environment and Forest b) Ministry of Commerce c) Ministry of Information) Ministry of Agriculture e) All Ministries f) Department of Forest g) Local Government Division h) Local i) Government Organization k) Bangladesh Forest Industries Corporation 1) Forest Research Institute m) BCSIR n) Planning Commission o) Department of Environment p) Science and Technology Division q) SPARRSO.

\section{Development Trends and Strategies}

After the independence of Bangladesh, the Government has undertaken various programs for the development of the forest and forest resources of Bangladesh.

First five-year Plan

- The existing forest area of the country is inadequate to meet the growing requirements of timber and firewood.

- By intensive resource management practices, making full use of production, potentials of these forestlands

- The minimum requirements of the country can be met by internal production of timber and firewood for some time more. 
- Judicious management of the mangrove forest of Sundarbans and extension of a forest belt along the coast for production of inland agricultural land and habitation.

- Making all use of homestead wasteland in rural and urban areas for planting trees through extension service.

- Bringing all available forestlands and potential forest lands under regular management of the forest service by reservation and use them for multiple benefits etc; [24].

Second Year Plan

- Acceleration of exploitation of the existing high forests of the hills and converting them into plantations.

-Making use of homestead land for planting trees and bamboo by strengthening and extending the existing extension efforts.

- Utilization of marginal lands for the introduction of non-traditional items such as rubber, oil palm, jack fruit etc.

- Raising plantation in the coastal areas and the offshore islands for protection against cyclones and tidal bore and stabilizing soil.

- Developing research and training programs.

- To adopt the concept of forestry for community development.

- To conduct scientific format management.

- To strengthen wildlife management and expand recreational facilities [25].

Third Five-year Plan

Under the third five-year plan, it has been observed that the activities of this year plan are as similar as that of the second five-year plan [26].

Fourth Five-year Plans (1990-95)

The objectives of the fourth five-year plan (1990-95) initiates the following plans for the development of the forest:

- Conservation of forests and development of forest resources (Government and Private), forest inventory, grading and quality control of forest products.

- Afforestation and regeneration of forest extraction of forest produce.

- Plantation of exotic cinchona and robber.

- Tree plantation.

- Planning cell-preparation of schemes and Coordination in respect of forest.

- Research and Training in Forest.

- Mechanized of forestry operations.

- Protection of wild birds and animals and established of sanctuaries [27].

Fifth five-year Plan

The main objectives of the fifth plan will be to expand forest resources, make forests productive, develop institutional capabilities and encourage people's participation:

- Conservation of vulnerable watersheds, protection of forests on step slopes and afforestation of blanks in much awareness.

- People's participation in augmentation forest resources through social forestry and community forestry program's.

- Preservation of genetic diversity of the flora and fauna [28].

From the above discussion, it is observed that the multi- dimensional expertise is required for the formulation of environmental policy which are lacking in Bangladesh [29].Therefore, government organizations and nongovernmental organizations have to strictly formulate and implement the environmental policies realizing from our own context. Recently, environmental consideration and administration has become a burning issue in Bangladesh. Since independence, different governments of Bangladesh have formulated and developed detailed policy frameworks in different times. The policy formulation gets priorities 1990s. It includes the National Environment Policy (1992), National Environment Action Plan (1992), Forest Policy (1994), Forestry Master Plan (1993-2012), Environment Conservation Act (1995), draft National Conservation Strategy, etc. Lastly, the National Environment Management Action Plan (NEMAP) has been prepared with wide participation of stakeholders and people at the grassroots level. The regulatory regime in Bangladesh, with about 200 environment-related laws, has a bearing effect on the environment, both direct and indirect. But studies around the world have shown that government regulation, as an instrument is inefficient, ineffective, and costly, in most of the cases. The policies sound more mission-like, with statements of pious objectives, rather than real policy direction. The Forest Policy states the need for establishing a triangular partnership among the Forest Department, the people and the NGO's, but there is no direction as to how the alliance will be forged. There is a chapter in the Industrial Policy (1991) on financial incentives to industries, but no incentive provision for industrial pollution control has been mentioned. The NEMAP is rightly highly praised for its grassroots level participation and as a reflection of people's concern about the environment. What is now needed is the use of economic policy instruments, including the pricing of environmental resources as a policy level for its effective implementation. A sound policy formulation requires trade-off between development and environmental objectives. This requires application of tools from environmental economics. Specifically, resource information and environmental indicators need to complement economic information for policy development. Thus, market mechanisms can do the job of deciding about this trade-off.All the above-mentioned policies are analyzed on the legal and sector basis and would like to inquiry how far it is implemented [30].Trees and forests, the great friends of human being and animals, provide food and shelter. Sheltered by some greedy and irresponsible political leaders men in the vicinity of forests are taking away forest resources indiscriminately. Because of this canopy layer and the undergrowth of forests are being destroyed on one hand and the sources of herbal medicines are getting destroyed on the other. Many of our wild animals and useful insects are facing extinction too. Adverse effects on climate and environment are taking place. Adopting illegal means the exploitation of the flora and fauna of the forests of the Sundarbans, Madhupur and Chittagong Hill Tracts are going on unabatedly. During the 60s a maund of Sundari wood used to sell 
in the local market for six taka. At present nowhere a mound of Sundari wood may be found for less than ten times that amount. Similar is the condition of other wood like Goran, Bain and Possure [31].The tree covered area of this densely populated country shrunk to merely less than six percent in 1995 from nearly 20 percent in 1927. This trend has no doubt serious consequences on the overall environmental conditions of the country. Consequently wildlife, bio-diversity, and human population have reached a point. It is believed that a country should possess at least 25 percent tree covered area in order to maintain its ecological balance. The climate and soil of Bangladesh are very much favorable for forest growth. In general, forest growth rate in Bangladesh is almost three times faster compared to the growth rate of humid temperate countries. Under such condition, rapid dwindling of Bangladesh forest area is indicative of several human induced factors. On the contrary, if our attention is focused toward India, we will find that both forestry and the stalk density are showing an increasing trend. At present, India's forest covered area is more than 40 percent. Bangladesh at present has a total forest land area of 2.6 million hectare. This includes 2.2 million hectare of state forest and 0.4 million hectare of private forestland. Out of the 2.2 million hectare of state forests 1.3 million hectare is managed by the Bangladesh Forest Department and the remaining 0.9 million hectare of Unclassified State Forests are managed by the district administration, village and homestead forests, tea estates and rubber plantations include 0.27 million hectare and 0.07 million hectare respectively. Bangladesh Forest Department manages forestry, which includes hill forests (0.6 million hectare), Sal forests $(0.12$ million hectare) and tidal mangrove forests (0.6 million hectare). In addition, there exists nearly 100,000 hectare of planted mangrove forests along the coast. The hill forests in the northern fringe, east and southeastern raglans of Bangladesh include Unclassified States Forests. Reserved Forests and Protected Forests. Hill forests have been broadly classified as Tropical Evergreen and Semi-Evergreen forests, which supply nearly 40 percent of the commercial timber to the market. The major timber growing species include garjan, civit, chandul, chapalish, shimul, toon, Korol, dhakl jam etc. In addition, there are plantations of teak, eucalyptus, dhakijam, garjan, mahogany, chapalish, shisoo, manglum and many other species. The undergrowth includes bamboo cane and fattanns, savanna and many other plant species of immense economic and environment values. The sal forests cover large area of the Madhupur tract in the central part and Barind tract in the northwest region. The sal forests at present is denuded, degraded, and encroached. The tree species of majoreconomic importance include sal (Shorearobusta) that cover nearly 70 percent of the tree population. Other species include korol, chambal, jogini choker, kalka, sidal, bazna, amlaki, sonalo, ajuli, gadila, etc. The Sundarbans cover nearly 6 million hectares of littoral forest that occur in the southwest part of Bangladesh and in the Chakoriathana of the Cox's Bazaar district. The tree species of major eco- nomic importance include sundari covering 73 percent of tree population, gewa, baen, keora, khalshi, dhundul, garjan, hental etc. Gewa population covers nearly 16 percent of trees in the Sundarbans. Other trees occupy the remaining 11 percent. The major tree species planted along the coastal area include keora, gewa, glopata, kakra, etc.

The major causes of forest degradation in Bangladesh include over-exploitation, sharp increase of population in the forest areas, socio-political unrest in Chittagong Hill Tracts, natural calamities, monoculture of trees, jhum cultivation, degradation of law and order situation, rapid urbanization rate that followed the liberation war of 1971, etc. In addition, poor policy framework, poor management, and institutional weakness also play their parts in the degradation of forests. Bangladesh Forest Department proved its ability in the management of state forests. The century old tradition of Bangladesh Forest Department has largely been eroded and the department has become sick now. Recruitment in the forestry professional and subordinate cadres has stopped since 1987. Nearly 150 non-cadres Assistant Conservator of Forest recruited under different development position. These officers, who possess forestry degree along with over 10 years' experience, suffer lack of service security and promotion opportunity. Consequently, the officers of Bangladesh Forest Department are increasingly becoming vulnerable because of the lack of training, promotion, and proper exposures. The Bangladesh Forests Research Institute, Chittagong, which is supposed to prove feedback to Bangladesh Forest Department with information generation through research, has been proved weak organization too. Out of its 153 , more than 60 posts are lying vacant since long. Unlike other research institutes the recruitment procedures are clumsy, time consuming and the recruitment rules are unacceptable to the staff of Bangladesh Forest Research Institute. The recruitment problem of Bangladesh Forest Research Institute will remain unresolved unless it is turned into an autonomous body. Bangladesh Forest Industrious Development Corporation is a bankrupt organization too. Its products are lying most often unsold. Degradations of natural forests in Bangladesh are causing degradation of floral and faunal bio-diversities, turning forests unsustainable, degrading the ecosystem which consequently is provoking flood and drought, affecting temperature and rainfall. As a resent, agricultural productivity is declining which in turn create rural poverty and social inequity. At present, forestry is taught as a discipline in Sylhet, Chittagong and Khulna universities. Bangladesh Agricultural University also created a department on Agro-forestry. Large numbers of graduates with degree on forestry are coming out every year form these universities. They, however, either face unemployment or lake employment in the non-forestry sectors. This is not only a kind of brain drain, but also wastage of taxpayer's money as per capita expenditure incurred for producing a forestry graduate is much higher than a general graduate [32].

It is mentioned that collective outlook should be reflected in all sectors of national development. Such programs 
should be undertaken and implemented with the inclusion of matters relating to environment. With his end in view and to prevent the declining nature of the environment, the government has promulgated the Environment Policy, 1992. This policy has been prepared with the intention of over-all and effective management of the environment. 15 different sectors have been defined and separate implementation programs have been drawn for them. The Environment Policy, 1992 contains the directives for the implementation of the steps taken to conserve environment at the national level with the coordinating efforts of government or semigovernment or autonomous organizations or departments. In order to encounter the problems related to environmental, all the 15 sectors would initiate necessary steps.

\section{Major Forest Legislations}

A good number of forest legislations are prevailing in the country. These Acts actively carried out significant role to the management and development of the forest and forest resources in Bangladesh. The existing forest laws bear relevance in environmental aspects of Bangladesh. In fact, almost countries have laws with regard to pollution, exploitation of mineral resources, and preservation of forests. However, application of such laws tends to be rare in many places, mostly in the poor countries, as political and economic interests overlap these. During the Mughal period (1203-1538), the forests were leased out by the local kings. The proper management and administration of forests were started in the 1860s after the establishment of a Forest Department in the province of Bengal. In this regard, some laws were enacted to develop and regulate the forest and forest resources [33].These rules and regulations were formulated on the basis of long-existing acts and policies. These laws were also amended, modified and improved upon over the time. Forest legislation in Bangladesh dates back to 1865 , when the first Indian Forest Act was enacted. It provided for the protection of tree, prevention of fires, prohibition of cultivation, and grazing in forest areas, until a comprehensive Indian Forest Act was formulated in 1927.

The Forest Act, 1927.

The forest Act [34]were passed in 1927 in order to consolidate the lawrelating to forests, the transit of forest produce and the duty leviable on timber and other forest produce [35]. This Act was amended in 1930. Since the partition of India, the Act was amended in 1949 and 1962. After the independence of Bangladesh, the forest Act was further amended in 1974 but the major changes was taken place in 1989. The forest Act was enacted to preserve and safeguard forest in general, both public and private. The Cattle, Forest Officer, Forest Office, Forest Produce, Owner, River Timber and Tree have been used for the implementation of this Act [36].This Act bears some important provisions 23 such as constitution of reserved forest, formation of any forestland or wasteland or any land suitable for afforestation will be the property of Government. It may be treated a mother Act of all the Acts. Because, rest of the Acts are enacted observing and considering the Forest Act, 1927 and in addition, this Act covers all procedural matters in implementation in all aspects related to forest conservation and development in Bangladesh. That is why; this Act is contributing largely for the conserving and developing the forest and forest resources in the countrywide. But it is regret that there is weakness in enforcement of the laws by forest officers due to legal and institutional shortcomings [37].

The Private Forests Ordinance, 1959.

This Acthas been passed in order to provide for the conservation of private forest and for the afforestation in certain cases of wastelands in Bangladesh [38]. Cattle, Conservation, Controlled Forest, Forest, Forest Produce, Private Forest, Timber, Tree, Vested Forest and Wasteland have been defined in this Act. In the development of the private forest, the government may help the owner of the private forest for conducting these forests and the owner shall carry out all terms and conditions in the working plans. The Government may take some initiatives in this regard. The inserting punishment of this Ordinance is very insignificant which should be enhanced immediately for the present need of the country.

The Cattle Trespass Act, 1871.

The Cattle Trespass Act25 is applicable in the reserved forest or in any portion of a protected forest [39]. It has already been lawfully closed to grazing in the forest. If the cattle caused to damage the plantation, then the forest officer or police officer may seize and impound them in the prescribed manner. There is a provision for fine in this act. The forest officer shall never be involved with the forest trade. Every person who exercises any right in a reserved or protected forest, or who exercises any right in a reserved or protected forest, or who is permitted to take any forest produce from, or to cut and remove timber or to pasture cattle, in such forest and every person who is employed by any such person in such forest, and every person in any village contiguous to such forest who is employed by the government or a local authority for services to be performed to the community, shall be bound to furnish without unnecessary delay to the nearest forest officer or police officer. The concern is that if any offences assisting any forest officer or police officer demanding his aid in preventing the commission in such forest of any offence, or, when there is reason to believe that any such offence has been committed in such forest, in discovering and arresting the offender, shall be punishable with imprisonment for a term which may extend to three months, or with fine which may extend to two thousand taka or with both. It seems that the inserting punishment is very insufficient to face the present socioeconomy conditions of the country. The punishment should immediately be enhanced so that the offenders do not think twice to commit those offences.

List of Forest Legislations.

Numerous Rules and bye-laws are framed by the Government to protect and develop the forest and forest resources of Bangladesh. These byelaws are basically applicable for the protection and preservation of the forest and 
forest resources in the areas of Chittagong and Chittagong Hill Tracts, Sylhet, Dinajpur and Rangpur and Sundarbans of Bangladesh. Here, most of the forest laws including byelaws are given below:

- The Forest Act, 1927.

- The Attia Forest (Protection) Ordinance, 1982.

- The Private Forests Ordinance, 1959.

- The Private Forests Ordinance, 1959.

- Drift Timber Rules For the Sundarbans Forest Division and for the Chittagong Hill Tracts Divisions and for Sylhet District, 1881.

- Sylhet Forest Transit Rules, 1951.

- The Forest Industries Development Corporation Ordinance, 1959.

- The Bangladesh wild life (preservation) Order, 1973.

- Dinajpur and Rangpur Forest Transit Rules, 1954.

- Sylhet Forest (Protection from fire) Rules, 1954.

- Rules for the Preservation of Trees and Timbers belonging to the government in the district of Chittagong, 1955.

- Rules Regarding Powers of forest officers under the Forest Act, 1959.

- The Chittagong and Chittagong Hill Tracts Reserved Forests Fire Protection Rules, 1958.

- Rules Regarding Powers of forest officers under the Forest Act, 1959.

- Prohibition and Rules Effecting Protected Forest in Sundarbans, 1959.

- Forest Transit Rules of Chittagong and Comilla Districts, 1959.

- Rules for the Control of Transit of Timber and other Forest produce and for the Measurement and registration of Boats used For Transit InSundarbans Forest Divisions, 1959.

- Dhaka Forest Transit Rules, 1959.

- Mymensingh Forest Transit Rules, 1959.

- Rules on Hunting, shooting and Fishing, 1959.

- The Forest Transit Rules, 1960.

-Rules For the Execution of Contracts by officers of Forest Department, 1960.

- Rules for Administration of lands along works, Housing and settlement communication and building Department roads passing through the Forest, 1960.

The Relevant other Legislationshaving relevance to Forest Conservation of Bangladesh [39].

There are substantive and procedural laws that have bearing relevance directly or indirectly on forests and forest resources of Bangladesh. These laws include a) The Bangladesh Penal Code, 1860, b) The Cattle trespass Act, 1871,c) The Evidence Act, 1872, d) The Limitation Act, 1877,e) The Code of Criminal Procedure, 1898, f) The Code of Civil Procedure, 1908, g) The State Acquisition and Tenancy Act, 1950, h) Rules made under the Protection and Conservation of Fish Act, 1950, I) The Government Land (Recovery of Possession and Building Act, $1952 \mathrm{j}$ ) The Acquisition and requisition of immovable Property Ordinance, 1982 k) Brick Burning ( control) Act, 1989. 1) The Elephant's preservation Act, 1879,m) The Wild Birds and Animals protection Ac, 1912, and n) the Bengal Rhinoceros Preservation Act, 1932.

All the above forest laws are passed to administer the forests and forest resources of Bangladesh. It is also mentioned that those laws related to forest have to be properly implementation for the forest environment and development of Bangladesh, which is a major part of our existence on earth.

\section{The Role of International Treaties Regarding Forest}

Some important international environmental laws as regards to conventions, treaties, conferences are held to protect and develop the forest and forest resources of the world. Bangladesh is a merely a signatory party because, those treaties have not yet been ratified. The signatory treaties of Bangladesh are briefly discussed here:

Convention on International Trade in Endangered Species of Wild Fauna and Flora.

The Government of Bangladesh signed this convention on 18.02.82. The purposes of this convention are to protect certain endangered species from over-exploitation by means of a system of import and export control.

Convention Concerning the Protection of the World Cultural and Natural Heritage.

The Government of Bangladesh signed this convention on 3.11.83 for the purposes of establishing an effective system of collective protection of the cultural and natural heritage of outstanding universe value, organize on a permanent basis and in accordance with modern scientific methods.

International Plant Protection Convention

The Government of Bangladesh signed on 01.09.78. The objective of this convention is to maintain and increase international cooperation in controlling pests and diseases of plants and plant products, and in preventing their introduction and spread across national boundaries.

Plant Protection Agreement for the Asia and pacific Regions.

The Government of Bangladesh signed this agreement on 1.9.78. The purpose of this agreement is to prevent the introduction into and spread within the region of destruction plant diseases and pests.

Conventions on Climate Change on Bio Diversity.

Bangladesh signed this convention in June 1992. It needs technical and institutional assistance to satisfy the convention.

Some other important International Conventions related to forest:

Some important international conventions are passed for the purposes of developing and conserving the different sectoral environments of the world. The under signed conventions are carried out its environmental considerations.

- Act of Foundation of a consultative committee for the International Protection of Nature, (Bernie), 1913. 
- Conservation for the protection of Migratory Birds in the United States and Canada, (Washington), 1916.

- Convention Relative to the Preservation of Fauna and Flora in their Natural State,( London), 1933.

- Convention for the Protection of Migratory Birds and Game Mammals, 1936.

- Convention on Nature Protection and Wildlife Preservation in the Western Hemisphere, (Washington), 1940.

- International convention for the Protection of Birds, (Paris), 195.

- Agreement for the Establishment on a Permanent Basis of a Latin American Forest Research and Training Institute, (Rome), 1959.

- Agreement concerning co-operation in the Quarantine of plants and their protection against pests and Disease, (Sofia), 1959.

- European Convention for the Protection of Animals during International Transport, (Paris), 1968.

- Benelux Convention on the Hunting and Protection of Birds; (Brussels), 1972.

- Convention on the Conservation of Migratory Species of Wild Animals (Bonn), 1979.

- Convention on the Conservation of European Wildlife and Natural Habitats, (Bernie), 1979.

The above mentioned legal instruments are used as legal mechanisms for the conservation and development of the forest biodiversities throughout the world for ensuring safe environment. It is observed that these mechanisms are not properly implemented due to technical defects such as resource constraints, lack of expertise. The study urges for the effective implementation of those mechanisms. The donors agency may come forward in this regard.

\section{Empirical Study and Discussion}

Most of the respondents argue that the implementation of laws and policies in forest are implemented partially i.e. it is implemented around 40 percent to 50 percent of the total implementations and the rest of the implementations are not carried out due to the following causes that may treated as barriers behind the implementation of forestry laws and policies of Bangladesh. These barriers may include sociocultural, legal etc., which are simultaneously discussed below:

Conservativeness

People living in the society are stick to conservativeness. This conservativeness lacks in the development of the society. The people of conservativeness lag behind in the case of advanced or developed society, which is an obstruction in the implementation of the forest laws and policies in Bangladesh.

Chaotic

Chaotic is one of the main barriers to the development sectors such as forestry, agriculture, fisheries etc., of Bangladesh. The chaotic situation or the people, who engage in this practice, create barrier in the implementation of forest laws and policies in Bangladesh.

\section{Lack of Co-Ordination}

The responsible Government's officials in the field of forestry, agriculture, fisheries etc., are not sincere to the subordinate officials. They do not pay heed to the concerned officials or the concern field staffs. The field staffs do not help the concerned authority sincerely. The government officials lack in co-ordination among the Government officials. For that reason, the smooth development is not possible to achieve. This kind of attitude is often observed in the implementation of forest laws and policies in Bangladesh. Lack of coordination amongst policies, districts and upazilla administrations and the Forest Department hampers enforcement of laws. The policy makers do not show any interest in making and improving co-ordination among the concerned officials for conducting and regulating the departmental activities of the country. They are always engaged in other activities such as consultancy, private welfare activities etc. They sometimes make contact among the officials for the purposes of the government functions. The MohiuddinFarooque in his book entitled "Regulatory Regime on Inland Fisheries in Bangladesh: Issues and Remedies" stated that in fisheries resources development, the institutional or the infrastructure facilities is not up to the mark rather it is weak in condition for which the fisheries resource depletion is on degradation. The lack of institutional accountability adds to the less developed of the forestry, fisheries etc. The forest and fisheries department largely depend on various sectoral departments. The diversified duties are assigned on many other agencies. As a result, the duties and responsibilities are not unified in shape. Consequently, the internal institutional capabilities become weak and the expected outcomes are not properly done. The policy framework also lacks in co-operationor co-ordination among the concerned agencies or stakeholders. For example, there is a 17 -member executive Committee under the Industrial policy (1991), but there is no representative from the Ministry of Environment or the Department of Environment.

Institutional Weakness

Institutional weakness of the Department of Forest is one of the causes for resource depletion. The Department of Forests is not as strong as the other departments. The diversified duties such as protection, exploitation, afforestation, extension, planning and training are assigned to a single professional cadre. The lack of institutional accountability adds to the panic.

\section{Corruption}

Corruption is alarmingly mounting rate in the forest. It is a great barrier to the development of forest and forest resources of Bangladesh. Moreover, this malpractice is going on in full length in the forest. Consequently, some problems such as drought, increasing the rate of temperature, are havoc to the development and environmental aspects of Bangladesh.

Insufficient Modern Facilities

The modern facilities are not enough for meeting up the present needs of the forest department. For that reason, the 
proper evaluation is possible to achieve. This insufficient facility creates problems in the implementation of forest laws and policies of Bangladesh.

Communication Gaps

The people in the society are not interested in dealing with the communication for achieving development in forestry, agriculture and fisheries etc., in the country. The lack of communication hinders problematic situations in all development issues of Bangladesh.

Unawareness

The people in our society are not aware about the rights and duties conferred upon them. So, unawareness of the people in the society is a great barrier to the development of the country; because they don't understand how to achieve development for their own happiness. The value and significance of the natural resources such as forestry, agriculture and fisheries are not evaluated properly due to awareness, which may be termed as a barrier in the implementation of forest laws and policies.

Elite Person's Pressure

The elite person in the society has a keen role for building up a happy society. They engaged themselves in politics and also in the development activities in the society for the interest of the people of the community. They sometimes involve in dirty politics and corruptions, which is called the village politics. It stands in the way of development in Bangladesh. The role of elites often makes problems in the implementation of the forest laws and policies of Bangladesh.

\section{Legal Barriers}

Application of environmental legislation is the prime need for ensuring public safety in Bangladesh. But the environmental laws vary from place to place due to diverse social and cultural factors. This may also vary due to economic potentials and needs. In fact, most of the countries have laws as to pollution, exploitation of mineral resources, preservation of forests etc. However, application of such laws tends to be rare in many places, mostly in the poor countries including Bangladesh, as these are overlapped by political and economic interests. In this aspect, Bangladesh faces some legal barriers, which are given below:

\section{Lack of Enforcement}

It is observed that the enforcement officers don't take necessary initiatives in the implementation of forest, agriculture and fisheries laws and policies in the country. It is notable that the necessary legal supporting mechanisms are also insufficient in the implementation of those laws. In this regard, Md. SaifulKarim has narrated his article titled "the Legal Framework for Conservation of Coastal and Marine Environment" that it is not a lack of legislation that is hampering the control of undesirable activities in coastal areas as much as the lack of enforcement of legislation. This lack of enforcement has resulted in the judiciary becoming actively involved in environmental protection as in India.

Lack of Trained Lawyers

It is reasonable to tell that there are many lawyers of different categories dealing in the legal matters in our country.
But it is regret that the environmental lawyers are hardly found to deal with the regulating environmental quality. That is why, the proper implementation of forest laws and policies are not smoothly done.

Insufficient Environmental Courts

The prevailing environmental courts are not enough in the execution of the forestry, agriculture and fisheries related environmental issues in Bangladesh. Although some civil courts are working dealing with forest and the fisheries cases yet, it is not satisfactorily done. Because, the civil courts are overburdened with other civil cases. Moreover, there are two environmental courts dealing with the environmental cases in two divisional headquarters in Bangladesh, which is very nominal in this respect.

Bureaucratic Problems

It is admitted in all hands that bureaucracy and corruption is the main obstruction in the development of forestry, agriculture, fisheries etc., of Bangladesh. At present, the country is overburdened with this problem. The bureaucracy feels interest in widening in the paper writing rather than the implementation of the development programs. The government faces many problems in the implementation of the development projects such as forestry, agriculture and fisheries etc., in the country. At present, the government should set up legal mechanisms like ombudsman to tackle these problems. It is mentioned that some professors such as Dr. M. ZainulAdedin of IBS, RU, Dr. KatshuhitoYahishimata (Japanese) and Dr. AnwarulHasan Sufi delivered their views in a saminar against the question raised by Noor Mohammad; research fellow held at IBS on 01.02.2005 that the corruptions may be eliminated by establishing Ombudsman in all administrative functionaries in the country. These strategies should be placed at the policy making. Moreover, they suggested us that the corruption may be rooted out by properly empowering the local representatives of the country and in this regard, the public representatives should be corruption less. In this regard, proper initiatives should be taken to eliminate the corruptions in all respects.

Non-compliance of "Polluter Pays" Principles

It is interesting to note that most of the lawmakers of our country are not acquainted with the formulation of law and policy due to lacking in educational qualifications. These lawmakers have to depend on the bureaucrats. But it is known to the bureaucratic that how to make ineffective laws and policies in the country. Consequently, the important and widely known effective provisions named 'the polluter pays principles' are not inserted to the environmental Acts and policies in the enforcement of the legal matters in the country. That is why; it is mentioned that the noncompliance of polluter pays principle is a great barrier in the implementation of the laws and policies in any sectors such as forestry, fisheries, agriculture etc., in the country. But if we study the environmental laws and policies of the developing countries such as New Zealand, China, USA, Australia etc., we can observe that pollution pays principle has been inserted to their laws and policies. 
Lack of Proper Authority in Issuing Licenses.

At present, environmental consideration is a burning issue now a day. Its importance is discussed everywhere in the world. But in the context of Bangladesh, it is often realized the importance of the environmental aspects. It is frequently absent in any development activities of the country. Besides, the development projects as well as the environmental issues are implemented mostly through the local government bodies such as thanaparishads, union parishads, zillaparishads, municipalities etc. Moreover, the government has empowered these institutions in many ways in different forms. But it is noted that the authorities of these institutions are not compliance with the environmental consequences. The authorities concerning environmental issues are not properly trained up and also they are not acquainted with the environmental issues in the most of the cases. So, the proper authorities in the case of environmental consideration are insufficient in the implementation of any environmental issues such as forestry, agriculture, fisheries etc., of the country. Lack of proper authority is a great barrier in any implementation of those laws and policies in the country.

Lack of Monitoring and Continuous Assessment

Monitoring and assessment are good instruments for achieving sustainable development in any country. Modern democracy emphasizes these systems. But it is not properly implanted in any development aspects such as forestry, agriculture and fisheries etc., of the country. In this regard, it is observed that lack of monitoring and continuous assessment is responsible for not implementation of any development activities of the environment in the country.

Lack of Qualified Planners or Policy Makers

Bangladesh is a democratic country. So, the democrats are conducting the country with the help of bureaucracy. That is why; the planners or the policy makers may not be qualified. Moreover, most of the bureaucrats are corrupted and not friendly to the environment of forestry or any sectors of Bangladesh. So, there is a great lacks in policy making for achieving sustainable development and environment in the country.

Lack of Holistic Approach

It is known to us that environment is a multi dimensional matter. So it requires the mutli dimensional measures to protect and conserve the environment such as forestry, fisheries, agriculture etc. That is why; the holistic approach for environmental protection measures is prerequisite for environmental conservation and development in the country. But it is regret that this attitude is absent in this regard.

Development Takes Priority over Environmental Considerations

The Government of Bangladesh implements various developments projects at the cost of millions or billions. These development projects are not properly done in accordance with the provisions of the Bangladesh Environment Conservation Act, 1995 and its Rules, 1997. Moreover, these projects are formulated and designed by the systems of bureaucracy. But the government authorities don't think twice or don't take priority basis over environmental aspects for the purposes of developing environment in the country. As a result, the proper and sustainable development of environment of forestry, fisheries, and agriculture in the country is not done.

Procedural and Structural Weakness of Bureaucracy in Implementation of Policies

The structure of bureaucracy of the government is very complex by nature and this system is inherited from the British colonial authorities. These systems were only dominating tendency and it was not for the people's participation oriented. This administration is at present in vogue in Bangladesh.It has not clear vision rather it is vague and unfriendly in the present context of Bangladesh. That is why; a significant change should be brought about in the policymaking. The present bureaucracy systems hinder the policy implications, which should be rooted out from the policy level for the purpose of sustainable development and environment of forestry, fisheries, agriculture etc., in the country.

\section{In adequate Information of Natural Resources}

Natural resources are the vast and important factors of the environment. Without natural resources, the environment is hardy observed. But it is regret that the government or the government authorities are not interested to know the importance of natural resources and information for the purposes of achieving sustainable development and environment in the country. Moreover, the scientific research is insufficient and it hinders the way of the development of the forestry, agriculture and fisheries in Bangladesh.

Bottom up Method

It is a method for collecting data and information from the field officers or concerned person who is quite known about those facts and circumstances and who is also may well known about the solution or policy implications. The concern persons of the modern age also believe in this method. It has been given much importance for the application of the bottom up method instead of top down method. Most of the concerned respondents requested to the authorities to implement the proper development issues of the country. Otherwise, the sustainable environment and development of forest, fisheries and agriculture is not possible to achieve. It is observed that bottom up method is blessing for any environment of the country.

\section{Recommendations}

From the experiences of the field visits, it is observed that the following policy implications may be taken as strategies for achieving sustainable development and environment of forest and forest resources of Bangladesh.

To Enhance Co-Ordination

From the point of experiences in the field investigation, it has been strongly suggested to the concerned authority to make co-ordination in full length among all the officers and staffs in all hands and to ensure well behavior for the proper implementation of the Government's activities. Every 
respondent has raised that coordination should immediately be ensured. The respondents urgently requested to make them conscious about the proper co-ordination. Without proper coordination, forestry, fisheries and agriculture etc., shall be seriously affected in the case of Bangladesh.

\section{Top down Method}

It is an imposing method. The policy makers or the planners sometimes impose some policies upon the executives for the implementation of the Government's development activities in Bangladesh. At present, the policy makers or the planners are applying this method. The scholars of the world criticized it seriously and they suggested for applying the bottom up method instead of top down method. Every field officer has claimed to change this method. This method does not solve the real problems. Now, it is harmful for the present context to meet the present needs of the country. Every one has suggested not to apply this method in context of present days needs.

\section{Elimination of Corruption}

Corruption means to adopt or to practice illegal activities. These activities are not permitted or legally protected by the legal systems of any country. Corruption is the greatest barriers to the development perspectives in any country of the world especially for Bangladesh. Every journal, Transparency International (TI reports) as well as the daily papers has focused seriously about the impact of the corruption on the development of Bangladesh. Every sector in Bangladesh like forestry, fisheries and agriculture involve in corruption. These should be immediately rooted out for the sake of the development in Bangladesh.

Political Appointment

The Government used to often appoint manpower for this position through the political manner. The persons who are involved in politics appointed for this position. It should be changed rather it would be appointed well-qualified persons. The Government should be careful about their appointment in policy making.

\section{Empowerment of the Technical Knowledge}

The policy makers or the policy planners are the heart of a nation. They should be well educated in all hands especially in the technical knowledge. They shall be empowered and technically sound for the present needs of the country. Without technical knowledge, the policy makers shall be not be well equipped in the implementation of forest laws and policies in the country.

\section{Contractual Service or Appointment}

The policy makers remain very busy at different purposes. This appointment should be made through the persons in the fixed term basis. This appointment should be renewal for the next term. The contractual service is widely applicable in the world at present. This practice should be introduced in the country in case of appointment in all levels considering all aspects of Bangladesh in comparison to world position.

\section{Logistic Support}

The logistic support means the facilities such as sufficient man power, equipment facilities, vehicles, sufficient salaries allowance, technical facilities, scientific facilities, infrastructure, residential areas, necessary academic and library facilities are to be provided as much as required in the forest or any other department of Bangladesh.

Management of Irregularities in the Office

It has a lot of irregularities such as disobedience to loyalty, absence of good relation, lack of social capital, discrimination among officers and staffs, insufficient facilities, unskilled man power, lack of trained personalities, etc., are often found in the office. The policy makers are to be sincere and also to be taken step for the proper implementation of the office management in the office of forestry, agriculture and fisheries etc., of Bangladesh.

Proper Evaluation of the Fitness

The proper evaluation means to give recognition of all the fitness including all academic attainments, training, vocational certificates, research and research activities, good performances and it should be properly evaluated for the better carrier of the Government service holders for bring about sustainable development and environment in forestry, agriculture and fisheries etc., of Bangladesh.

\section{Establishing Natural Justice}

Some principles of natural justice such as right to selfdefense, hearing the both parties, etc, of the administrative laws is to be appropriately ensured in the case of justice among the officers related to any fields. The policy planners are to be careful for maintaining the principles of natural justice for bring about sustainable development in any fields such as forestry, agriculture, fisheries etc., of Bangladesh.

Practical Knowledge to be needed

Sometimes, it is noted that the policy makers are not equipped in the practical knowledge for the proper implementation of the government activities. But it is urgently needed to have this knowledge to conduct the concerned department smoothly. The policy makers should be careful about the proper utilization of the practical knowledge in any field of Bangladesh.

Careful about the Bureaucratic Policy

The policy makers and the bureaucrats are closely related in the implementation of the development issues such as forestry, agriculture, fisheries etc., in Bangladesh. As a result, the dual administration is after found in the administration. They always influence each other. As the bureaucrats are trained up in all respects, so the policy makers shall be aware of them for the implementation of the project activities in respect of Bangladesh.

To Acquire Knowledge about the theory of Development

As the policy makers as well as the executives are staying at the corner of development perspectives in Bangladesh. So, the policy makers and the executives should have thoroughly knowledge about the theory of development especially the development for what and development for whom. The policy makers and the executives should be well known to the development activities and its acquiring policies in the implementation of forestry, agriculture and fisheries etc., of Bangladesh. 
Free From Political Involvement

The appointed policy makers and the executives sometimes deal with the politics. This political involvement affects the project implementation like fisheries, forestry and agriculture etc. They should be highly free from political involvement and the Government should be quite conscious about their appointment.

Motivational Technique to be applied

Sufficient motivational problem exists in the field officers. The officers and the subordinates are not habituated in practicing motivational activities in the field where the projects are implemented. At present, a few motivational programs have been undertaken for the preservation and protection of the environment and development. The policy makers or the executives should take necessary steps in the implementation of the governmental policies in forestry, fisheries and agriculture etc., in Bangladesh.

Appointment of the Local Consultant

The foreign consultants are appointed as consultant in the country instead of local consultant. But it is a matter of great regret that the foreign consultants are not properly acquaintant with the local problems. Moreover, they are paid huge amount of money. So it might be a problems in the development of Bangladesh and the social problems of the country may not be solved though the proper utilization of her resources. In this regard, considering our own problems, the local consultant should be given priorities in the implementation of legal matters concerning forest and any other matters connected therewith.

To Reduce Bureaucratic Attitudes in the Grass Root Levels through the Fiduciary Relations

The fiduciary relations among all the staffs should be enhanced for the proper management for achieving development in forestry, fisheries and agriculture in Bangladesh. It is noted that there is a great hazard in the field officers like district officers to union level officers and for that reason, the hazardous situation is continuing in the forestry, fisheries, and agriculture. The Government should take appropriate step for removing the discriminatory activities and the necessary measures should be taken immediately for sustainable development and environment of Bangladesh.

Ensuring Good Governess

The administration or the governance in forestry, fisheries and agriculture of Bangladesh is not satisfactory in all hands. The principles of good governance are absent in this administration. At present, the said proverb proves that the lawmakers are the lawbreakers in Bangladesh. So it is clearly said that the desirable good governance is not ensured in the country. The government should be aware in this matter.

\section{Removing of the Administrative Weakness}

There is much weakness such as corruption, untrained personalities, discrimination in salaries and allowances etc., in the administration. These should be removed and the transparency is to be maintained and established in the administration. The Government should aware of this section for appropriate action.
Co-ordination among all the Administrative Organs to be ensured

The co- ordination among all the departments such as Water and power Development Authority (WAPDA), Road and High ways, Local Government Engineering Department (LGED), forestry, agriculture, fisheries, etc., should be enhanced for the proper management of those agencies. It could have done for the interest of the nations building.

The Policy Maker should sit at the Problem Oriented Areas

The policy makers in general sit at Dhaka based office, the capital city. They are not able to find out the actual problems and its possible solutions. They sometimes want to know from the executives for gathering information. Although they want it, they do not take further action for the implementation. If the Government sends the policy makers to the problem-oriented areas or the problem facing areas, it may be a wise act for the proper implementation in forestry, fisheries, agriculture etc., in Bangladesh.

Frequent Visiting and Inspection Systems to be introduced

Visiting and inspection system is one of the processes for achieving success of any area such as forestry, fisheries etc. It is proven that it has a great importance for improving development activities. But it is rarely found in the field administration. Sometimes it is found in inspection through the audit team. But it is also corrupted. As a result, development is not possible up to the expectation.

Japanese Systems to be Introduced

The Japanese systems in relation to forestry, agriculture, fisheries and other sectors or services are to be introduced in policy making. In Japan, the service structure or pattern like annual confidential report (ACR), performances, activities in the officers and staffs, salaries and allowance are integrated in the concerned officers; staffs and other related staffs. They evaluate one another performances and it is submitted to the proper authorities in the particular purposes, which is different from that of Bangladesh and other countries of the world. It seems that the Japanese systems are to be introduced in the case of implementation of forest laws and policies.

The Field Officers to be Included in the Policy Making

The policy makers are host in themselves. They are not interested in participating in the field officers for the proper implementation of the governmental activities. It affects the development and environment of the country. If the Government and the policy maker include them for making policy, the country will get more fruitful result. The Government and the policy maker should take care in the implementation of the forest laws and policies in the country.

The Relevant Policy and its Implementation to be ensured

The Government has formulated some policies in fisheries, forestry and agriculture and so on sectors in Bangladesh. But these policies are hardly implemented.It is written in the form of document. This tendency is also a problem in the implementation of the forest laws and policies in Ban- 
gladesh. The policy paper needs implementation.

To Increase Budgetary Allocation

The policy makers or the planners should aware about the preparation of the budget, which has been introduced in the financial year. The fisheries, forestry and agriculture etc., have been suffering much for want of budgetary allocations. These allocations are not properly regulated or maintained in implementation of forestry, agriculture and fisheries etc., for which the sustainable development is not possible to achieve. The Government as well as the policy makers may enhance budgetary allocation in these sectors for sake development and environment of Bangladesh. The insufficient budget makes hindrance to the implementation of forest laws and policies.

Formulation of the Newly Recruitment Rules

It is observed that there is discrimination in the recruitment rules procedure especially in the fisheries, forest sectors of Bangladesh. That is why; the sufficient recruitment is not possible. The Government and the policy maker should investigate and eliminate these anomalies in recruitment It ultimately makes barrier in the implementation of forest and fisheries laws and policies in Bangladesh.

To Increase Man Power

Every department of the Government has been suffering and has been affecting much for want of manpower. Without proper utilization of manpower, development is impossible. So, manpower should urgently be recruited for the vacant position in the implementation of development activities in Bangladesh. Administrative Transparency is to be maintained for the rooted out of the administrative hazards through the Accountability. The administration is fully occupied with corruption, mismanagement, irregularities, undutiful etc., and there is no transparency in the administration. As a result, the administrative hazards are prevailing in the country. The Government should immediately interfere upon the administration for the better management of the admini09stration for ensuring development and environment of the country. Moreover, the people's welfare oriented administration is to be reorganized for Bangladesh, which is a demand of the present world. The people welfare administration is prevailing in the world. We should follow the developing countries administration for bring about sustainable development and environment of the country.

Special Days like Weekly, Fortnight Days Monthly etc to be observed for awareness Building

It is hardly found the observance of the weekly, monthly days in fisheries, forestry and agriculture of Bangladesh. It has been a great impact on the people's concentration for awareness building for the proper implementation of the above sectors in Bangladesh. The Government should observe some special days in the months of a year, which may carry significant values to the related programs for which the development may be possible for the country.

Awarding Systems to be introduced

At present, it is observed the awarding systems of the fisheries sectors of Bangladesh but it is not satisfactorily done. On the other hand, the awarding systems are not found in the forest department. The Government may introduce the awarding system for attainment so that the concern persons will get much inspirations for their work for which the significant progress may be possible to achieve.

\section{Conclusion}

From the above discussion, it is observed and found the concept of the preservation of the forest and forest resources was found in the British period. Later on, it has been developed gradually. After the independence of Bangladesh, the government of Bangladesh has developed much. Many initiatives such as such as enactment of new laws, policies etc., are passed for the preservation of the forest and forest resources of Bangladesh. But this sector didn't adequately developed due to non-coordination, insufficient penal provisions, lack of enforcement of laws, ineffective provisions of forest laws and policies etc. The government may rethink and consider about the implementation procedures of law and policy in the country. The government should aware about the effective implementation of forest and forest related laws and policies for achieving sustainable environment and development of those areas of Bangladesh. The Department of Forest are implemented many projects such as Community Forestry Development Project, Nursery Development Project, Social Forestry Project etc; funded by ADB for the purpose of attaining sustainable development and environment in the forest areas of Bangladesh. The training programs of the forest department should be much more effective for the stakeholders. In this regard, the Government may consider the policy implications framed in this research for the sake of bringing about sustainable forest environment and development of Bangladesh. We should be more aware and effective about the Green South Asia, 2007. Finally, it should be understood that the wildlife conservation including all other species is possible to preserve and conserve by the proper implementation of the above mentioned forest laws and policies in Bangladesh. It will helpful for the sustainable nature conservation. Some new laws and policy should be introduced considering our own state and needs compared to developed countries of the world.Let us think over collectively and sincerely for the proper implementation of our national and international mechanisms for the sake of our own existence.

\section{Acknowledgements}

First of all record, my profound sense of gratitude to my direct reverend professor and also my doctoral research supervisor Dr. M. RabiulHossain and his wife Ms. SufiaHossain, Professor \& Provost and ex-Dean, Faculty of Law and my co-supervisor Dr. M. Mostafa Kamal, Associate Professor, Institute of Bangladesh Studies, University of Rajshahi for their scholarly and painstaking supervision, inspirational support, untiring guidance and sympathetic co-operation at all stages of my research, without which 
this study as a part of my $\mathrm{PhD}$ researchwould not have been possible. During my research work, I have received cordial help and positive attitude from both the respected supervisors, particularly, Dr. M. RabiulHossain who doesn't know how to speak negative approach to the research fellows. He constantly helps and dearly loves me. On the other hand, Dr. M. Mostafa Kamal always helps me in all respects. It is notable that, he has provided me with his own personal chamber at IBS for my research work for day and night. Both my supervisors who spared no pains to hold my energy up in the work. I could not complete this work but for the constant supervision and encouragement of my guide it has got its present stage. Simple words of thanks and acknowledgements cannot express any gratitude to them.

I would like to acknowledge my indebtedness to the Institute of Bangladesh Studies, University of Rajshahi for offering me all kinds of academic supports and facilities for this research work. I am grateful to my teacher Dr. M. ZainulAbedin, Professor and Director, IBS, Ex-Director Professor Dr. Priti Kumar Mitra, Dr. SwarachishSarkar and Mr.JakirHossain, Assistant Professor of IBS and other related teachers at IBS for their valuable suggestions during my research. Besides, M. ZaidurRahman, M. ShahajanRari, M. Fazlul Hague Akonda, M.A. Abdus Salam Akon, M. AftabHossain along with all staffs have helped me much at IBS.

I would like to express my gratitude to Dr. Begum AsmaSiddiqua, Professor, Department of Law \& Justice and A.N.M. Wahid, Chairman, at the department for their valuable guidance and inspirations in my research career. I am also grateful to all my respected teachers at the Department of Law \& Justice, Rajshahi University.

I would like to acknowledge with thanks to all my classmates particularly M. AminulHaque, AnkhiBhabi, A.S.M. Ekramulla, Dr. Mst. RehenaSiddiqua, Dr. Uttam Kumar Das, Dr. M. Khabiruddin, Dr.A.k.M. AkhtarulKabir, LubnaApa, AzamBhai, KaziHasan Kamal, BakulBhai, Sumon, Sharmi etc., and rest of the fellows at IBS for sharing ideas and views with me. Besides, I also thank to the respondents and relevant personality who directly or indirectly helps me during my research work.

I would like to acknowledge to Dr. A.F.M. ShamsurRahman, Professor of History, University of Rajshahi, Chairman Md. AyubHossain Khan and MdTabiburRahman, Lecturer JhicargachaMohilla College, Jessore and members of Kastovanga Union ParishadKaligonj, Jhenidah, Md.HabiburRahman, Md. SabdarHossain, Md. AbdusShukur, Abdul Hannah Md. RezaulKarim, Md. Shariful Islam Khan, Mami, M. MocklesurRahman etc., has kindly helped me much. Without their help especially both the Chairmen, I could not proceed on. I am bound to gratitude to them forever in addition to my supervisors.

I would like to acknowledge to the Metropolitan University Sylhet, Bangladesh for encouraging supports towards me for doing research and development. Additionally, I would like to acknowledge to some important related international conferences including the UiTM for presenting the findings of this research work and so on.

I would like to express my gratitude to all that I have been developing my teaching and research career by participating in the different national and international conferences, seminars, workshops etc.

I am indebted to my wife, Mrs. Rokeya Sultana (Bulu), who suffered a lot during my long period of deep engagement with this 00000 study but offered me all kinds of help, co-operation and inspirations. I am also indebted to my mother, brothers, sisters, Bhabi, Lantu, Taz, Sheuly, tinny brothers and nephew and niece and other relatives whose love and affection always inspired me to complete this thesis.

Last but not least, it is kindly noted that it is my first draft and you may kindly forgive my weaknesses.

\section{Dedicated To}

In the memory of the Metropolitan University, Sylhet\& Bangladesh University, Dhaka where I started my teaching career and have been considered as foundations and inspirations of my research endeavors (Please pray for them \& ALL).

\section{References}

[1] GOB, Bangladesh Economic Review, 2003, Economic Adversary's Wing, Finance Division, Ministry of Finance, June, 2003.

[2] A.N. ShamsulHoque, "Environment and Health Bangladesh Experience: An Overview", Journal of the Institute of Bangladesh Studies (JIBS), Vol. 17, June 1994, p. 5.

[3] M. Salar Khan, et al. Bangladesh Environment : Facing the 21st Century, Philip Gain (ed.) (Dhaka : Society for Environment and Human Development (SHEHD, 1998), p. 41

[4] MohiuddinFarooque, Law and Custom on Forests in Bangladesh: Issues \& Remedies (Dhaka: Bangladesh Environmental Lawyers Association, 1997), p. 96.

[5] Serajul Islam(ed.), National Encyclopaedia of Bangladesh, Vol. 4 (Dhaka : Asiatic Society of Bangladesh, 2003), p. 248.

[6] GOB, Department of Forest, 2001.

[7] Neaz Ahmed Siddiqui, Mangrove Forest in Bangladesh (Chittagong : Institute of Forestry and Environmental Sciences, Chittagong University, 1997), p. 25.

[8] Serajul Islam(ed.), National Encyclopaedia of Bangladesh, Vol. 4 (Dhaka : Asiatic Society of Bangladesh, 2003), p. 248.

[9] National Forest Policy, 1979.

[10] M. Salar Khan, et al. op.cit.

[11] MohiuddinFarooque, Regulatory Regime on Inland Fisheries in Bangladesh : Issues and Remedies (Dhaka : Bangladesh Environmental Lawyers Association, 2001),p. 152.

[12] Environment Policy and Action Plan, 1992.

[13] MohiuddinFarooque, Regulatory Regime on Inland Fishe- 
ries in Bangladesh : Issues and Remedies.

[14] GOB, First Five-Year Plan, 1973-78, November 1973. Ministry of Planning, Dhaka.

[15] GOB, The Second Year Plan, 1978-80, September, 1978 Ministry of Planning, Dhaka.

[16] GOB, The Third Five Year Plan, 1985-90, Ministry of Planning, Dhaka.

[17] GOB, The Fourth Five Year Plan, 1990-95, Ministry of Planning, Dhaka.

[18] GOB, The Fifth Five-Year Plan, 1997-2002, Ministry of Planning, Dhaka.

[19] Mizan Khan, "Environmental Policy-making in Bangladesh", Bangladesh State of Environment Report, 1999, Dhaka, pp. 217-218.

[20] "To End Deforestation", Weekend Independent, 15 February 2002.

[21] M.M. Hassan, "The Dwindling Forests on Bangladesh", The Bangladesh Observer, February 28, 1999, p. 5.

[22] Serajul Islam(ed.), National Encyclopaedia of Bangladesh
Vol. 4 (Dhaka : Asiatic Society of Bangladesh, 2003), p. 248.

[23] The Forest Act'1927 (Act No. XVI of 1927).

[24] MohiuddinFarooque, Law and Custom on Forests in Bangladesh: Issues \& Remedies, p. 15.

[25] The Private Forests Ordinance, 1959 (Ordinance No. XXXIV of 1959).

[26] Other Legislations include substantive and procedural laws. Definitions of Substantive and Procedural Law are mentioned here. Law defines the rights, which it will aid and specifies the way in which it will aid them. So far it defines, thereby creating, it is "substantive law." So far it provides a method of aiding and protecting it is Procedural or "Adjective law." Dr. TahirMahmood. N.S. Bindra, Interpretation of Statutes, 7th ed. (Allahbad : The Law Book Company LTD, 1984), p. 646.

[27] MohiuddinFarooque, Law and Custom on Forests in Bangladesh: Issues \& Remedies, p. 15.

[28] Mizan Khan, "Environmental Policy-Making in Bangladesh", pp. 217-218.

[29] MohiuddinFarooque, Law and Custom on Forests in Bangladesh: Issues \& Remedies, p. 17. 